\title{
A profile of patients treated at a national leprosy outpatient referral clinic in Rio de Janeiro, Brazil, 1986-2007
}

\author{
Mariana A. Hacker, ${ }^{1}$ Anna M. Sales, ${ }^{1}$ Ximena Illarramendi, ${ }^{1}$ \\ Jose A. Nery, ${ }^{1}$ Nadia C. Duppre, ${ }^{1}$ Francisco I. Bastos, ${ }^{2}$ \\ and Euzenir N. Sarno ${ }^{1}$
}

Suggested citation

Hacker MA, Sales AM, Illarramendi X, Nery JA, Duppre NC, Bastos FI, et al. A profile of patients treated at a national leprosy outpatient referral clinic in Rio de Janeiro, Brazil, 1986-2007. Rev Panam Salud Publica. 2012;31(6):485-91.

\begin{abstract}
Objective. To analyze a profile of patients treated at a national leprosy outpatient referral clinic in metropolitan Rio de Janeiro, Brazil, over a period of more than two decades, and the subgroup of nationally registered leprosy cases from the same residential area, as well as all registered cases statewide.

Methods. An observational, descriptive analysis was carried out for patients treated from 1986 to 2007 at the Souza Araújo Outpatient Clinic (Ambulatório Souza Araújo, ASA), a national referral center for the diagnosis and treatment of leprosy at the Oswaldo Cruz Foundation (Fiocruz) that serves clients from the city of Rio de Janeiro and other municipalities in the metropolitan area of Rio de Janeiro State. Demographic and clinical data for the subgroup of leprosy cases registered with Brazil's National Disease Notification System (Sistema Nacional de Informação de Agravos de Notificação, SINAN) between 2001 and 2007 and residing in the same municipalities as the ASA patients, and for all registered cases statewide, were also analyzed.

Results. Among the ASA patients, there was a decrease in average family income (from 3.9 to 2.7 times the minimum salary between the periods 1998-2002 and 2003-2007); the proportion of multibacillary ( $M B$ ) patients (from $52.7 \%$ to $46.9 \%$ ); and the proportion of patients younger than 15 years old (from $12.8 \%$ to $8.7 \%$ ). Among the MB patients, the average initial and final bacilloscopic indices were significantly higher in 2003-2007. Compared with the SINAN cases, more ASA cases involved disability and were younger than 15 years old.

Conclusions. Patients living with leprosy in the metropolitan area of the state of Rio de Janeiro belong to the most deprived social strata and have not benefited from the overall improvement in socioeconomic conditions in Brazil.
\end{abstract}

Key words Leprosy, outpatient clinics, hospital; socioeconomic factors; social inequality; Brazil.

Leprosy is a chronic infectious disease caused by Mycobacterium leprae, an obligate intracellular parasite (1). Over

\footnotetext{
1 Laboratório de Hanseníase, Instituto Oswaldo Cruz, Fundação Oswaldo Cruz (Fiocruz), Rio de Janeiro, Brazil. Send correspondence to: Mariana A. Hacker, marianah@ioc.fiocruz.br

2 Laboratório de Informação em Saúde, Instituto de Comunicação e Informação Científica e Tecnológica em Saúde (ICICT), Fundação Oswaldo Cruz (Fiocruz), Rio de Janeiro, Brazil.
}

the last few years, most leprosy-endemic countries have reached their elimination goals (i.e., a prevalence less than 1/10 000 inhabitants). Nevertheless, clusters of high prevalence persist in some areas of Africa, Asia, and South America, particularly in India and Brazil (2).

Despite Brazil's recent economic growth and comprehensive, albeit het- erogeneous, public health care system, which provides universal health care and includes specific initiatives focused on reducing leprosy $(3,4)$, it still has the second-highest number of newly detected cases of leprosy per year (after India). Prevalence of the disease persists, even though Brazil's health care system has successfully implemented effective 
solutions to other more complex and costly problems such as HIV / AIDS (5).

In 2008, the leprosy prevalence rate in Brazil was 20.56 cases per 100000 inhabitants, with 38992 new cases reported that year. Prevalence varies widely across the country, with higher rates reported in the North, Northeast, and Central-West regions versus the more economically prosperous South and Southeast regions $(6,7)$. However, even in the most developed part of the country-the Southeast (8)-leprosy persists in underserved areas such as favelas (slums). For example, in 2008, the highly industrialized southeastern state of Rio de Janeiro had a prevalence rate of 11.84/100 000 inhabitants (7).

Brazil's National Leprosy Program was created in 1992. As per the World Health Organization (WHO) multidrug therapy (MDT) protocol (9) established in 1982, a minimum of two years of treatment was recommended for multibacillary (MB) patients. Prior to the introduction of the WHO protocol, the recommended treatment was continual treatment until a negative bacilloscopy was obtained. However, the long duration of the former treatment strategy had become an obstacle to its success. In 1997, WHO revised its protocol for treatment of MB patients (10) by reducing the number of recommended doses of MDT from 24 to 12 over an 18-month period (11).

According to reports published by Brazil's Ministry of Health and WHO, Brazil's adoption of these new procedures has contributed to earlier diagnosis and reduced incidence of both MB leprosy and cases with disabilities $(12,13)$. Nonetheless, leprosy prevalence continues to persist in underserved areas.

The current study analyzed 1) the profile of patients treated at Souza Araújo Outpatient Clinic (Ambulatório Souza Araújo, ASA), a national referral center for the diagnosis and treatment of leprosy that serves clients from the city of Rio de Janeiro and other municipalities in the metropolitan area of Rio de Janeiro State, and 2) clinical and demographic data for the subgroup of nationally registered leprosy cases from the same municipalities as the ASA patients, and for all registered cases statewide, retrieved from the Ministry of Health's National Disease Notification System (Sistema de Informação de Agravos de Notificação, SINAN).

\section{MATERIALS AND METHODS}

\section{Study site}

An observational, descriptive analysis was carried out using data for 1) leprosy patients treated and followed up at the ASA from 1986 to 2007, and 2) all leprosy patients registered with SINAN between 2001 and 2007 and living in the same municipalities as the ASA patient sample ("co-resident cities") versus all registered cases statewide. The ASA is a main referral center for leprosy patients. Referral centers are an important source of data for discerning new trends in epidemics and the associated consequences because they concentrate a large number of patients (especially those with serious medical conditions) who are referred by a network of health units (14). The majority of ASA patients $(\sim 70 \%)$ are referred from other health care services, while about $6 \%$ come to the center seeking help of their own accord, about $16 \%$ are identified through a disease surveillance program conducted among leprosy patient contacts, and about $8 \%$ have other forms of detection. After leprosy is confirmed via clinical, histopathological, and bacteriological tests, the patients are treated and followed up. Since 1986, all socioeconomic, clinical, and laboratory data related to ASA patients have been routinely recorded.

\section{Study period}

The clinical course, treatment regimen, and incubation period for leprosy can be quite lengthy. To allow for more accurate study of the disease, the study period was divided into four segments: 1986-1992, 1993-1997, 1998-2002, and 2003-2007. The first segment corresponded to the period following Brazil's implementation of the standard MDT protocol (9). The second segment corresponded to the period following the introduction of WHO's policy advocating suspension of MDT in multibacillary patients after two years of treatment, regardless of the patient's bacilloscopic index (BI) (15). The third segment corresponded to the period following implementation of the revised WHO protocol that reduced the number of doses from 24 to $12(10,11)$. The last segment corresponded to the period following the Brazilian government's reaffirmation and strengthening of its commitment to eliminate leprosy, at the Second Meeting of the Global Alliance for the Elimination of Leprosy (GAEL) (Brasilia, 29-31 January 2002), where the country also assumed the GAEL presidency (16).

\section{Study classifications and statistical analysis}

As per the criteria of Ridley and Jopling (17), the current study divided patients into two polar groups on the immunological spectrum (tuberculoid leprosy [TT] and lepromatous leprosy [LL]), and three intermediate disease types (borderline-tuberculoid [BT] leprosy, borderline-borderline [BB] leprosy, and borderline-lepromatous [BL] leprosy).

Patient examinations were carried out by the ASA, which, as of 1998, has also housed a neurological clinic specializing in the diagnosis and management of pure neural leprosy (PNL). Laboratory techniques used by the clinic include electrophysiological assays, nerve biopsy examinations, and polymerase chain reaction (PCR) detection of M. leprae. PNL is characterized by sensory changes and an absence of skin lesions (18).

In the current study, skin specimens were collected for bacteriological examination and the determination of the $\mathrm{BI}$ using a WHO-approved technique (19). The BI was measured at diagnosis and after treatment. Patients with positive BIs were classified as "MB" and those with negative BIs were classified as " $\mathrm{PB}^{\prime}$ (paucibacillary). The disability grade ${ }^{3}$ was evaluated at the time of diagnosis and after treatment. The data for the ASA patients were analyzed by comparing socioeconomic and disease characteristics over time.

Chi-squared tests for linear trends and analysis of variance (ANOVA) were used to investigate differences between the data from the different study segments. The statistical significance level was set at $5 \%$.

The data for all leprosy cases registered in the state of Rio de Janeiro (available only from 2001 onward) were retrieved from the SINAN database (www. datasus.gov.br) and additional analyses were conducted to describe the available

\footnotetext{
Based on 1988 World Health Organization disability grading scale (0, "no impairments"; 1 , "leprosy-related impairment but visual acuity $\geq 6 / 60$ (eyes)" and "sensory impairment" (hands and feet); 2, "visual acuity $<6 / 60$, laghophthalmos" and "visible deformities" (hands and feet)).
} 
demographic and clinical characteristics of patients who resided in the co-resident cities and those registered statewide.

The Ethics Committee of the Oswaldo Cruz Foundation (Fiocruz) approved the use of the study data for research and publication.

\section{RESULTS}

\section{ASA socio-demographic, clinical, and laboratory data}

From 1986-2007, 2213 patients were treated at the ASA (Table 1). There was a slight predominance of males in all of the study segments (varying from $56.3 \%$ to $58.6 \%$ ). Gender distribution was not statistically different across the study period $(P=0.241)$. The proportion of patients 15 years or younger significantly decreased over time, especially during the last three study segments (varying from $14.3 \%$ to $8.7 \% ; P=0.034$ ). Of all cases studied across the entire study period, $50.0 \%$ to $55.8 \%$ were white ( $P=0.367), 31.3 \%$ to $37.0 \%$ were multiracial $(P=0.463)$, and $10.4 \%$ to $15.5 \%$ were black $(P=0.019)$.

Most ASA patients had received eight years or less of formal education. Average family income (in minimum salaryminimum living income necessary for a worker to meet basic needs, periodically adjusted according to inflation) decreased from 3.9 to 2.7 (number of times minimum salary) between the periods 1998-2002 and 2003-2007.

A significant difference was observed between the operational classifications of leprosy described above. The proportion of $\mathrm{MB}$ patients decreased from $52.7 \%$ and $54.7 \%$ in the first and second study segments respectively to $42.5 \%$ and $46.9 \%$ in the third and fourth study segments respectively $(P=0.001)$. The proportion of BL patients decreased from $23 \%$ in the first study segment to $18.8 \%$, $14.9 \%$, and $15.5 \%$, in the second, third, and final study segments respectively $(P<0.001)$. The BT classification was the most prevalent, comprising $31.8 \%$ of cases in the first study segment, $34.0 \%$ in the second segment, $34.8 \%$ in the third segment, and $35.4 \%$ in the fourth segment $(P=0.534)$. A substantial increase was observed in the clinical form of PNL, from $0.7 \%$ and $2.7 \%$ in the first and second study segments respectively to $11.0 \%$ and $9.1 \%$ in the third and fourth study segments respectively $(P<0.001)$.
TABLE 1. Socio-demographic and clinical characteristics of leprosy patients treated at the Souza Araújo Outpatient Clinic (ASA), Rio de Janeiro, Brazil, 1986-2007

\begin{tabular}{|c|c|c|c|c|c|}
\hline \multirow[b]{2}{*}{ Variable } & \multicolumn{4}{|c|}{ No. $(\%)^{a}$} & \multirow[b]{2}{*}{$P$} \\
\hline & $\begin{array}{c}1986-1992 \\
(n=882)\end{array}$ & $\begin{array}{c}1993-1997 \\
(n=448)\end{array}$ & $\begin{array}{c}1998-2002 \\
(n=538)\end{array}$ & $\begin{array}{c}2003-2007 \\
(n=345)\end{array}$ & \\
\hline \multicolumn{6}{|l|}{ Gender } \\
\hline Female & $336(41.5)$ & $186(41.5)$ & $235(43.7)$ & $143(41.4)$ & \multirow{3}{*}{0.241} \\
\hline Male & $516(58.5)$ & $262(58.5)$ & $303(56.3)$ & $202(58.6)$ & \\
\hline Total & 852 & 448 & 538 & 345 & \\
\hline \multicolumn{6}{|l|}{ Age } \\
\hline$<15$ years & $113(12.8)$ & $64(14.3)$ & $58(10.8)$ & $30(8.7)$ & \multirow[t]{3}{*}{0.034} \\
\hline$\geq 15$ years & 769 (87.2) & $348(85.7)$ & $478(89.2)$ & $314(91.3)$ & \\
\hline Total & 882 & 412 & 536 & 344 & \\
\hline \multicolumn{6}{|l|}{ Race } \\
\hline White & $466(53.2)$ & $220(50.0)$ & $297(55.8)$ & $186(54.7)$ & 0.367 \\
\hline Multiracial & $274(31.3)$ & $163(37.0)$ & $180(33.8)$ & $112(32.9)$ & 0.463 \\
\hline Black & $136(15.5)$ & $57(13.0)$ & $55(10.4)$ & $42(12.4)$ & \multirow[t]{6}{*}{0.019} \\
\hline Total & 876 & 440 & 532 & 340 & \\
\hline Presence of sanitation & $-{ }^{b}$ & - & $504(97.9)$ & $333(100)$ & \\
\hline Total & & & 515 & 333 & \\
\hline Masonry housing & - & - & $511(98.6)$ & $333(100)$ & \\
\hline Total & & & 518 & 333 & \\
\hline \multicolumn{6}{|l|}{ Education } \\
\hline Illiterate & - & - & $35(6.6)$ & $17(5.1)$ & 0.352 \\
\hline$\leq 8$ years & - & & $361(68.1)$ & $243(72.3)$ & 0.189 \\
\hline$>8$ years & - & - & $134(25.3)$ & $76(22.6)$ & \multirow[t]{2}{*}{0.373} \\
\hline Total & & & 530 & 336 & \\
\hline \multicolumn{6}{|l|}{ Operational disease classification } \\
\hline Multibacillary (MB) & $462(52.7)$ & $245(54.7)$ & $228(42.5)$ & $161(46.9)$ & \multirow[t]{2}{*}{0.001} \\
\hline Paucibacillary (PB) & $415(47.3)$ & $203(45.3)$ & $309(57.5)$ & $182(53.1)$ & \\
\hline Total & 877 & 448 & 537 & 343 & \\
\hline \multicolumn{6}{|l|}{ Clinical disease form } \\
\hline Lepromatous leprosy (LL) & $166(18.9)$ & $81(18.1)$ & $79(14.7)$ & $83(24.3)$ & 0.450 \\
\hline Borderline-lepromatous (BL) & $202(23.0)$ & $84(18.8)$ & $80(14.9)$ & $53(15.5)$ & $<0.001$ \\
\hline Borderline-borderline (BB) & $92(10.5)$ & $78(17.4)$ & $68(12.7)$ & $24(7.0)$ & $<0.001$ \\
\hline Borderline-tuberculoid (BT) & $279(31.8)$ & $152(34.0)$ & $187(34.8)$ & $121(35.4)$ & 0.534 \\
\hline Tuberculoid leprosy (TT) & $9(1.0)$ & $22(4.9)$ & $19(3.5)$ & $8(2.3)$ & $<0.001$ \\
\hline Indeterminate (I) & $124(14.1)$ & $18(4.0)$ & $45(8.4)$ & $22(6.4)$ & $<0.001$ \\
\hline Pure neural leprosy (PNL) & $6(0.7)$ & $12(2.7)$ & $59(11.0)$ & $31(9.1)$ & $<0.001$ \\
\hline Total & 878 & 447 & 537 & 342 & \\
\hline \multicolumn{6}{|l|}{ Pre-treatment disability grade ${ }^{c}$} \\
\hline 0 & $496(59.8)$ & $305(70.3)$ & $341(64.1)$ & $226(67.5)$ & 0.018 \\
\hline 1 & $183(22.0)$ & $68(15.7)$ & $81(15.2)$ & $68(20.3)$ & 0.074 \\
\hline 2 & $151(18.2)$ & $61(14.0)$ & $110(20.7)$ & $41(12.2)$ & 0.247 \\
\hline Total & 830 & 434 & 532 & 335 & \\
\hline \multicolumn{6}{|l|}{ Post-treatment disability grade } \\
\hline 0 & $459(66.2)$ & $259(70.0)$ & $288(68.7)$ & $147(66.2)$ & \multirow[t]{4}{*}{0.218} \\
\hline 1 & $133(19.2)$ & $61(16.5)$ & $74(17.7)$ & $51(23.0)$ & \\
\hline 2 & $101(14.6)$ & $50(13.5)$ & $57(13.6)$ & $24(10.8)$ & \\
\hline Total & 693 & 370 & 419 & 222 & \\
\hline Treatment dropout & $57(6.5)$ & $15(3.3)$ & $19(3.5)$ & $8(2.3)$ & 0.001 \\
\hline Total & 882 & 448 & 538 & 345 & \\
\hline Family incomed ${ }^{d}\left(\right.$ mean; $\left.S D^{e}\right)$ & - & - & $(3.9 ; 4.9)$ & $(2.7 ; 3.1)$ & $<0.001$ \\
\hline Total & - & - & 491 & 294 & \\
\hline Pre-treatment $\mathrm{BI}^{\dagger}$ (mean; SD) & $(2.7 ; 1.2)$ & $(2.7 ; 1.5)$ & $(2.2 ; 1.4)$ & $(3.3 ; 1.3)$ & $<0.001$ \\
\hline Total & 379 & 229 & 224 & 156 & \\
\hline Post-treatment BI (mean; SD) & $(1.1 ; 1.2)$ & $(1.4 ; 1.4)$ & $(1.7 ; 1.5)$ & $(2.6 ; 1.5)$ & $<0.001$ \\
\hline Total & 365 & 209 & 173 & 74 & \\
\hline
\end{tabular}

a Number and percentage of valid cases (based on availability of data).

b Data not available.

c At diagnosis; based on 1988 World Health Organization disability grading scale (0, "no impairments"; 1, "leprosy-related impairment but visual acuity $\geq 6 / 60$ (eyes)" and "sensory impairment" (hands and feet); 2 , "visual acuity < 6/60, laghophthalmos" and "visible deformities" (hands and feet)).

d Number of times minimum salary.

e SD: standard deviation.

f Bl: bacilloscopic index among MB patients. 
There was significant variation in the pre-treatment disability grade across the four study segments. In the first segment, $59.8 \%$ of the patients had grades of zero, versus $70.3 \%$ in the second segment, $64.1 \%$ in the third segment, and $67.5 \%$ in the fourth segment $(P=0.018)$. A sizable percentage of the patients (varying from $17.4 \%$ to $35.6 \%$ ) were not evaluated for post-treatment disability. For those that were, no statistically significant differences were found across the four study segments.

Among the MB patients, the average BIs at diagnosis and after treatment were significantly higher in the last study segment versus the first three study segments. However, in the last segment there was a high proportion of missing data $(25.2 \%)$ for the post-treatment BI, which compromised further comparisons. Across the entire study period there was a significant decrease (from $6.5 \%$ to $2.3 \% ; P=0.001)$ in dropout rates (discontinuation of treatment).

\section{SINAN demographic and clinical data}

From 2001 to 2007, among the cases of leprosy registered in the SINAN database and residing in the same Rio de Janeiro metropolitan area cities as the ASA patients ("co-resident cities") $(n=12$ 804) and all SINAN-registered cases from Rio de Janeiro State $(n=22$ 086), the proportion diagnosed as having no disability (a grade of " 0 ") at diagnosis ("pre-treatment") decreased from 77.5\% to $72.5 \%$ and from $75.5 \%$ to $71.1 \%$ respectively over the study period (Table 2 ).

The same trend was observed for the post-treatment disability grade, which decreased from $80.8 \%$ to $75.5 \%$ in the coresident cities and from $78.7 \%$ to $74.8 \%$ statewide over the same period (20012007). The proportion of cases diagnosed with grade 1 disability pre-treatment increased from $14.3 \%$ to $19.2 \%$ in the coresident cities and from $16.5 \%$ to $20.6 \%$ statewide over the study period. A lesspronounced increase was observed in the proportion of cases with grade 1 disability post-treatment (from $13.0 \%$ to $16.8 \%$ in the cases from the co-resident cities and from $15.1 \%$ to $17.5 \%$ statewide). The proportions of cases evaluated as grade 2 disability before and after treatment remained similar over time but were smaller overall post-treatment. As mentioned above, a high percentage of cases (varying from $31.1 \%$ to $41.2 \%$ )

TABLE 2. Demographic and clinical characteristics of all SINANa-registered leprosy cases statewide versus those in "co-resident cities,"” Rio de Janeiro State, Brazil, 2001-2007

\begin{tabular}{|c|c|c|c|c|}
\hline \multirow[b]{3}{*}{ Variable } & \multicolumn{4}{|c|}{ No. $(\%)^{c}$} \\
\hline & \multicolumn{2}{|c|}{ Rio de Janeiro State } & \multicolumn{2}{|c|}{ Co-resident cities } \\
\hline & $\begin{array}{l}2001-2002 \\
(n=6874)\end{array}$ & $\begin{array}{l}2003-2007 \\
(n=15212)\end{array}$ & $\begin{array}{l}2001-2002 \\
(n=4118)\end{array}$ & $\begin{array}{l}2003-2007 \\
(n=8686)\end{array}$ \\
\hline \multicolumn{5}{|l|}{ Gender } \\
\hline Female & $3480(50.6)$ & $7776(48.9)$ & $2105(51.1)$ & $4313(49.7)$ \\
\hline Male & $3392(49.4)$ & $7433(51.1)$ & $2012(48.9)$ & $4372(50.3)$ \\
\hline Total & 6872 & 15209 & 4177 & 8685 \\
\hline \multicolumn{5}{|l|}{ Age } \\
\hline$<15$ years & $420(6.1)$ & $949(6.2)$ & $236(5.7)$ & $532(6.1)$ \\
\hline$\leq 15$ years & $6454(93.9)$ & $14263(93.8)$ & 3882 (94.3) & $8154(93.9)$ \\
\hline Total & 6874 & 15212 & 4118 & 8686 \\
\hline \multicolumn{5}{|c|}{ Operational disease classification } \\
\hline Multibacillary (MB) & $3549(51.9)$ & 8008 (52.9) & $2029(50.6)$ & $4447(51.4)$ \\
\hline Paucibacillary (PB) & $3288(48.1)$ & $7121(47.1)$ & $2078(49.4)$ & $4212(48.6)$ \\
\hline Total & 6837 & 15129 & 4107 & 8659 \\
\hline \multicolumn{5}{|c|}{ Pre-treatment disability grade ${ }^{d}$} \\
\hline 0 & $4443(75.5)$ & $9680(71.1)$ & $2754(77.5)$ & $5710(72.5)$ \\
\hline 1 & $974(16.5)$ & $2801(20.6)$ & 509 (14.3) & $1510(19.2)$ \\
\hline 2 & $471(8.0)$ & $1133(8.3)$ & $290(8.2)$ & $654(8.3)$ \\
\hline Total & 5888 & 13614 & 3553 & 7874 \\
\hline \multicolumn{5}{|c|}{ Post-treatment disability grade } \\
\hline 0 & $3182(78.7)$ & $7056(74.8)$ & $2105(80.8)$ & $4517(75.5)$ \\
\hline 1 & $608(15.1)$ & $1652(17.5)$ & $340(13.0)$ & $1005(16.8)$ \\
\hline 2 & $251(6.2)$ & $719(7.6)$ & $161(6.2)$ & $458(7.7)$ \\
\hline Total & 4041 & 9427 & 2606 & 5980 \\
\hline Treatment dropout & $461(6.7)$ & $786(5.2)$ & $279(6.8)$ & $490(5.6)$ \\
\hline Total & 6876 & 15216 & 4120 & 8688 \\
\hline
\end{tabular}

a Brazil's National Disease Notification System (Sistema Nacional de Informação de Agravos de Notificação).

b Same municipalities as those of primary study sample (leprosy patients treated and followed up from 1986-2007 at Souza Araújo Outpatient Clinic in Rio de Janeiro).

c Number and percentage of valid cases (based on availability of data).

'At diagnosis; based on 1988 World Health Organization disability grading scale (0, "no impairments"; 1 , "leprosy-related impairment but visual acuity $\geq 6 / 60$ (eyes)" and "sensory impairment" (hands and feet); 2 , "visual acuity < 6/60, laghophthalmos" and "visible impairments" (hands and feet)).

did not receive a post-treatment disability evaluation. The proportion of patients who dropped out of treatment decreased from $6.8 \%$ to $5.6 \%$ in the coresident cities and from $6.7 \%$ to $5.2 \%$ statewide over the study period.

\section{DISCUSSION}

A slight majority of ASA patients were male and most had completed only eight years or less of formal education; a minority of cases 1) involved children younger than 15 years and 2) had disabilities.

Substantial gender differences among leprosy patients have been found in terms of general knowledge about leprosy, propensity to seek treatment, and delay in diagnosis. Some authors have identified social, cultural, and economic factors associated with stigma faced by women living with leprosy (20-22). Morrison (2000) suggested that future strategies to prevent, control, and treat leprosy should address gender differences more thoroughly (23). Although various stud- ies have shown an increased demand for health services among Brazilian women over time (24-27), the stigma associated with leprosy appears to be connected to social and gender inequalities in complex ways (28).

The proportion of patients who lived in homes with proper sanitation was higher in the later study segments, similar to the situation across Brazil (4), despite persistent regional heterogeneities. Nevertheless, the data revealed a decrease in patient family income among the periods analyzed, in marked opposition to what has been observed in recent years in Brazil, where income has not only increased substantially but has become much more fairly distributed (4). The limited amount of formal education among the majority of leprosy patients may explain their apparent difficulty in obtaining well-paying jobs, even within the context of economic growth. Although the scope of the current study does not allow for conclusions to be drawn about economic impacts related 
to leprosy, the decrease in family income among individuals affected by leprosy observed in the current study was most likely a result of reduction of risk among medium- to low-income families.

Unfortunately, diseases such as hepatitis B that may be prevented by vaccines (available to any Brazilian citizen at no cost) and neglected diseases such as leprosy still cluster in the most disenfranchised populations in Brazil. These groups appear to have received little or no benefit from Brazil's economic growth and social progress (29-32).

Based on the current study results, the same can be said with regard to ASA leprosy patients, who did not appear to have benefited from Brazil's economic growth or improved income distribution, which has included comprehensive cash transfers to impoverished populations. This disquieting finding appears to be related to these patients' position in the most disenfranchised strata. Despite recent progress, Brazil remains plagued by social, economic, gender, and other forms of prejudice and marginalization $(27,28)$.

Although the capital city of Rio de Janeiro is the second most affluent municipality in the country (8), Rio de Janeiro State continues to have a high endemic level of leprosy. As shown elsewhere (30-32), leprosy is directly related to social inequalities and shortcomings in the health care system. This is the case even in a state like Rio de Janeiro, which is equipped with an extensive network of public (and private) health care centers.

A number of governmental initiatives in Brazil have been implemented in recent years to increase the employment rate (while at the same time fostering a more competitive labor market, which has benefited people with higher levels of education) and provide higher incomes (e.g., increasing the minimum salary, even with deflating monetary values) as well as cash transfers (through social programs). These improvements have translated into improved public health outcomes for most, but not all, population strata (27).

Reducing the prevalence of leprosy requires improvements in various areas at both the individual and family level (e.g., better education and more accurate self-perceptions of health and disease) and in contextual determinants such as scope of preventive measures, quality of diagnoses, and accessibility of effective health care programs.
A larger proportion of patients under 15 years of age were observed among ASA patients versus SINAN-registered cases from the co-resident cities in Rio de Janeiro State for the period 2003-2007. Since June 1987, the ASA has conducted routine examinations of leprosy patient contacts and provided health care information to the patients and their families. Both strategies may have facilitated earlier detection of the disease over time. The diagnosis of leprosy in children less than 15 years old is an indicator of high endemicity and early exposure to the disease and is thus an important element for assessing the magnitude of the disease within a specific locality and time period (12).

The reduction in $\mathrm{MB}$ cases observed among the ASA patient sample from the current study may be a consequence of improved diagnosis (including the specialized techniques for identifying PNL). Disease prevention efforts and examination of patient contacts have revealed that the $\mathrm{PB}$ form of the disease generally predominates, possibly as a result of early detection. Conversely, it can be assumed that prevalence of the MB form of the disease indicates delays in diagnosis. Prevalence of the PB form has been considered an indicator of an "active endemic process" (i.e., one that remains endemic, with relatively high prevalence rates and a relevant number of new cases over time, preferentially affecting individuals who are more resistant to infection). The vast majority of cases diagnosed in areas of low prevalence are the MB form.

Susceptibility to infection is a natural characteristic of the host. The current study could not assess biological factors that may have been associated with different outcomes because of the lack of comprehensive genetic data for the majority of the patients being followed up at the ASA.

The operational classifications used in the routine treatment of ASA patients are based on the BI, and all cases with positive skin smears are classified as MB. This approach is different from other health care centers in Brazil where BIs are not considered and the disease classification is based on the number of detected skin lesions.

Over time, the percentage of ASA cases presenting as the PNL clinical form increased. This may be due to the high number of referrals of patients with challenging nerve disorders of leprosy and/or the optimal performance of ASA's neurological services, which are not available elsewhere in the state. Although the BL form of the disease dropped significantly in $\mathrm{MB}$ cases among the ASA patients, the LL form increased during the last study segment, which may have contributed to the increase in post-treatment BI cases.

The disability grade has been used as an indicator for timeliness of diagnosis, based on the assumption that the presentation of grades 1 and 2 constitutes evidence of a late diagnosis. Among cases reported nationwide in Brazil, a reduction in the percentage of deformities was detected during the 1987-1997 period (33). This trend was not observed among the ASA patients in the current study.

In the current study, for the 2003-2007 study segment, a higher proportion of cases with disabilities was found among the ASA patients versus the SINAN-registered cases, indicating that 1) the ASA patients had a more severe level of disease than leprosy patients followed up at primary health care facilities in the coresident cities and/or 2) the severity of the cases treated at those primary health care facilities was underestimated. A recent study conducted at a referral center in Brazil's Northeast region showed a significant portion of patients with some disability, which may also reflect the level of disease severity found among patients who have been referred to or have sought out specialized care (14).

Non-compliance with treatment can lead to the development of resistant bacilli. In the current study, the proportion of patients who dropped out of treatment was low, and decreases in treatment dropout rates among ASA patients and SINAN-registered cases were observed over the study period. For the period 2003-2007, the proportion of noncompliance was lower among the ASA patients versus the SINAN cases.

Although no significant differences in treatment outcomes have been found between patients on the 24-month regimen and those on the revised [12-month] regimen (34), the current study showed that post-treatment BIs were higher in the later study segments corresponding to the use of the revised regimen. This may be at least partially attributable to the slow process of bacterial clearance, which continues beyond the completion of the revised regimen (35). Despite the 
high BIs recorded after the shorter, more concentrated treatment period, patients are considered cured once they complete the revised regimen (10).

A study to assess leprosy elimination strategies undertaken in Duque de Caxias, a city in metropolitan Rio de Janeiro, showed that strategies such as the decentralization of patient care and targeted campaigns proposed by Brazil's Ministry of Health and WHO $(12,13)$ were associated with an increase in early detection and a reduction in the prevalence rate (36).

The reduction in the number of patients being followed up at the ASA in recent years appears to be related to reductions in both spontaneous demand and referrals, resulting in turn from increased access to primary health care and/or a decreasing prevalence of leprosy. Since 1989, all Brazilians have been entitled to free health care, through a national health system that has recently undergone decentralization of management (promoting greater adequacy of health services in terms of the regional needs of the population), and increased access to primary health care, through Brazil's Family Health Strategy, established in 1993 (27).

Successive changes to Brazil's leprosy program in the areas of epidemiological surveillance; management structure; integration of care; and communication, education, and research were implemented according to the recommenda- tions of WHO and Brazil's Ministry of Health (9-13). These modifications led to an increase in earlier diagnoses and thus contributed to the decreased proportion of MB leprosy cases revealed in the results of this study.

Despite its adoption of the WHO guidelines for eliminating leprosy, Brazil continues to face major challenges in the prevention and diagnosis of the disease. Martelli et al. (37) have argued that despite the decline in prevalence following the introduction of MDT, the incidence of leprosy in Brazil remains unacceptably high.

The current study has many limitations. First, data on leprosy cases registered in the state of Rio de Janeiro are only available for the year 2001 and beyond, precluding any comparisons of study segments other than the period 2001-2007. Second, data for the posttreatment disability evaluation were available only for a fraction of the ASA patients and SINAN-registered cases, compromising the conclusions about this key variable. In addition, other variables, such as "education level," "presence of sanitation," "masonry housing," and "family income," could not be analyzed for the first two study segments because the corresponding data were not systematically collected. Third, because of referrals, the ASA sees cases that are more complex than those registered with SINAN. As a result, the ASA patients are not representative of SINAN- registered patients. Therefore, like the results of any clinically based sample that is not representative of the reference population, the current study results do not allow for reliable determination of whether the observed changes are epidemiological or represent changes in the demand of patients and/or diagnostic capacity/accuracy.

However, because referral centers such as ASA tend to have the capacity for optimal diagnosis and in-depth assessment, their findings may help identify new trends in an epidemic and thus foster the development of new strategies and tools to prevent and control the spread of the disease. Future research on relapse rates and pre- and post-MDT disability grades is recommended, with a focus on disability-the main concern of patients and the biggest threat to public health.

The current study results confirmed that leprosy has yet to be eradicated in modern-day Brazil, even in the secondmost industrialized state in the country. The disease remains concentrated (and may become more clustered) in the underserved strata of Brazilian society despite the social and economic improvements that have occurred within the country as a whole. Although improved referral and diagnostic procedures seem to have contributed to earlier detection of the disease, there is still much to be done to effectively control leprosy in Brazil.

\section{REFERENCES}

1. Gallo ME, Sampaio E, Nery JA, Moraes MO, Antunes SL, Pessolani MC, et al. Hanseníase: aspectos epidemiológicos, clínicos e imunológicos. In: Coura JR, editor. Dinâmica das doenças infecciosas e parasitárias. Rio de Janeiro: Editora Guanabara Koogan; 2005. Pp. 1383-94.

2. World Health Organization. Global leprosy situation. Wkly Epidemiol Rec. 2009;84(33): 333-40. Available from: http:/ / www.who.int/ wer/2009/wer8433/en/index.html

3. Ministério da Saúde, Gabinete do Ministro [BR]. Portaria $n^{\circ} 2.048$, de 3 de Setembro de 2009. Brasília: MS; 2009. Available from: http://portal.saude.gov.br/portal/arquivos/ pdf/regulamento_sus_240909.pdf

4. Instituto Brasileiro de Geografia e Estatística [BR]. Comentários. Pesquisa Nacional por Amostra de Domicílios [Internet]. Rio de Janeiro: IBGE; 2007. Available from: http://www.ibge.gov.br/home/estatistica/ populacao/trabalhoerendimento/pnad2006/ comenta rios2006.pdf Accessed 7 July 2009.
5. Bastos FI, Nunn A, Hacker MA, Malta M, Szwarcwald CL. AIDS in Brazil: the challenge and the response. In: Celentano DD, Beyrer C, editors. Public health aspects of HIV/AIDS in developing countries: epidemiology, prevention and care. New York: Springer International; 2008. Pp. 629-54.

6. Magalhaes MC, Rojas, LI. Diferenciação territorial da hanseníase no Brasil. Epidemiol Serv Saude. 2007;16:75-84.

7. Ministério da Saúde [BR]. Hanseníase no Brasil-dados e indicadores selecionados. Brasília: MS; 2009. Available from: http:// portal.saude.gov.br/portal/arquivos/pdf/ caderno_de_indicadores_hanse_brasil_01_ a08_atual.pdf

8. Instituto Brasileiro de Geografia e Estatística [BR]. Produto Interno Bruto dos Municipios 2003-2007 [Internet]. Rio de Janeiro: IBGE; 2008. Available from: http://www.ibge.gov. $\mathrm{br} /$ home/estatistica/economia/pibmunici pios/2003_2007/default.shtm Accessed 26 May 2010.
9. World Health Organization. Chemotherapy of leprosy for control programmes: report of a WHO study. WHO Technical Report Series No. 675. Geneva: WHO; 1982.

10. World Health Organization. Shortening duration of treatment of multibacillary leprosy. Wkly Epidemiol Rec. 1997;72(18):125-8. Geneva: WHO; 1997.

11. World Health Organization. WHO Expert Committee on Leprosy. Sixth report. WHO Technical Report Series No. 768. Geneva: WHO; 1988.

12. Ministério da Saúde [BR]. Plano Nacional de Eliminação da Hanseníase em nível municipal. 2006-2010. Brasília: MS; 2006. Available from: http://www.hanseniase.fespmg.edu.br/ images/stories/artigo/hanseniaseplano.swf

13. World Health Organization. WHO Global Strategy Report 2006-2010. Geneva: WHO; 2006. Available from: http://www.who.int/lep/ strategy/report2006-2010/en/index.html

14. Gomes CC, Pontes MA, Gonçalves HS, Penna GO. Perfil clínico-epidemiológico dos pacien- 
tes diagnosticados com hanseníase em um centro de referência na região nordeste do Brasil. An Bras Dermatol. 2005;80(Supl 3): S283-8.

15. World Health Organization. Progress towards the elimination of leprosy as a public health problem. Wkly Epidemiol Rec. 1993;68(25): $181-6$.

16. Ministério da Saúde [BR]. Guia para o controle da hanseníase. Brasília: MS; 2002. Available from: http://bvsms.saude.gov.br/bvs/ publicacoes/guia_de_hanseniase.pdf

17. Ridley DS, Jopling WH. Classification of leprosy according to immunity: a five-group system. Int J Lepr Other Mycobact Dis. 1966; 34(3):255-73.

18. Jardim MR, Antunes SL, Santos AR, Nascimento OJ, Nery JA, Sales AM, et al. Criteria for diagnosis of pure neural leprosy. J Neurol. 2003;250(7):806-9.

19. Ministério da Saúde [BR]. Guia de procedimentos técnicos para baciloscopia em hanseníase. Brasilia: MS; 2010. Available from: http://portal.saude.gov.br/portal/arquivos/ $\mathrm{pdf} /$ guia hanseniase $100039 \mathrm{~m}$ final.pdf

20. Peters ES, Eshiet AL. Male-female (sex) differences in leprosy patients in south eastern $\mathrm{Ni}$ geria: females present late for diagnosis and treatment and have higher rates of deformity. Lepr Rev. 2002;73(3):262-7.

21. Kumar RB, Singhasivanon P, Sherchand JB, Mahaisavariya P, Kaewkungwal J, Peerapakorn S, et al. Gender differences in epidemiological factors associated with treatment completion status of leprosy patients in the most hyperendemic district of Nepal. Southeast Asian J Trop Med Public Health. 2004;35(2):334-9.
22. Phaff C, Van Den Broek J, MacArthur A Jr, Ndeve A, Stuip Y. Characteristics and treatment outcomes of leprosy patients detected during a leprosy elimination campaign in Mozambique compared with routinely detected patients. Lepr Rev. 2003;74(3):229-39.

23. Morrison A. A woman with leprosy is in double jeopardy. Lepr Rev. 2000;71(2):128-43.

24. Rosa Filho LA, Fassa AG, Paniz VM. Fatores associados à continuidade interpessoal na atenção à saúde: estudo de base populacional. Cad Saude Publica. 2008;24(4):915-25.

25. Barata RB, de Almeida MF, Montero CV da Silva ZP. Gender and health inequalities among adolescents and adults in Brazil, 1998. Rev Panam Salud Publica. 2007;21(5):320-7.

26. Oliveira MH, Romanelli G. Os efeitos da hanseníase em homens e mulheres: um estudo de gênero. Cad Saude Publ. 1998;14(1):51-60.

27. Victora CG, Barreto ML, do Carmo Leal M, Monteiro CA, Schmidt MI, Paim J, et al. Health conditions and health-policy innovations in Brazil: the way forward. Lancet. 2011;377(9782):2042-53

28. Heijnders ML. The dynamics of stigma in leprosy. Int J Lepr Other Mycobact Dis. 2004; 72(4):437-47.

29. Barreto ML, Teixeira MG, Bastos FI, Ximenes RA, Barata RB, Rodrigues LC. Successes and failures in the control of infectious diseases in Brazil: social and environmental context, policies, interventions, and research needs. Lancet. 2011;377(9780):1877-89.

30. Helene LM, Salum MJ. A reproduçäo social da hanseníase: um estudo do perfil de doentes com hanseníase no Município de São Paulo. Cad Saude Publica. 2002;18(1):101-13.
31. Cunha SS, Rodrigues LC, Duppre NC. Current strategy for leprosy control in Brazil: time to pursue alternative preventive strategies? Rev Panam Salud Publica. 2004;16(5):362-5.

32. Duarte MT, Ayres JA, Simonetti JP. Socioeconomic and demographic profile of leprosy carriers attended in nursing consultations. Rev Lat Am Enfermagem. 2007;15 Spec No:774-9.

33. Ministério da Saúde [BR]. Hanseníase no Brasil: progressos e dificuldades em relação à eliminação. Brasília: MS; 1998.

34. Sales AM, Sabroza PC, Nery JA, Dupprè NC, Sarno EN. No difference in leprosy treatment outcomes comparing 12- and 24-dose multidrug regimens: a preliminary study. Cad Saude Publica. 2007;23(4):815-22.

35. Kumar A, Girdhar A, Girdhar BK. Pattern of bacillary clearance in multibacillary leprosy patients with multidrug therapy. Acta Leprol. 2003:12(3):123-8.

36. Cunha MD, Cavaliere FA, Hércules FM, Duraes SM, Oliveira ML, Matos HJ. Os indicadores da hanseníase e as estratégias de eliminação da doença, em município endêmico do Estado do Rio de Janeiro, Brasil. Cad Saude Publica. 2007;23(5):1187-97.

37. Martelli CM, Stefani MM, Penna GO, Andrade AL. Endemias e epidemias brasileiras, desafios e perspectivas de investigação científica: hanseníase. Rev Bras Epidemiol. 2002;5(3):273-85.

Manuscript received on 4 April 2011. Revised version accepted for publication on 28 October 2011.

RESUMEN Objetivo. Analizar el perfil de los enfermos tratados en un servicio nacional de remisión de pacientes ambulatorios con lepra ubicado en la zona metropolitana de Río de Janeiro, Brasil, durante más de dos decenios, y el subgrupo de casos de lepra registrados a nivel nacional de la misma zona de residencia, así como todos los casos registrados a nivel estatal.

Perfil de los enfermos tratados en un servicio nacional de remisión de pacientes ambulatorios con lepra en Río de Janeiro, Brasil, 1986-2007

Palabras clave Lepra; servicio ambulatorio en hospital; factores socioeconómicos; inequidad social; tratados des pacientes en el servicio ambulatorio Souza Araújo (ASA), un centro de remisión nacional para el diagnóstico y el tratamiento de la lepra en la Fundación Oswaldo Cruz, que atiende a pacientes de la ciudad de Río de Janeiro y de otros municipios de la zona metropolitana del Estado de Río de Janeiro. También se analizaron los datos demográficos y clínicos del subgrupo de casos de lepra registrados con el Sistema Nacional de Notificación de Enfermedades del Brasil (SINAN) entre el 2001 y el 2007 residentes en los mismos municipios que los pacientes atendidos en el ASA, y de todos los casos registrados a nivel estatal.

Resultados. En los pacientes atendidos en el ASA hubo una disminución en los ingresos familiares promedio (de 3,9 a 2,7 veces el sueldo mínimo entre los períodos 1998-2002 y 2003-2007), en la proporción de pacientes multibacilares (de 52,7\% a 46,9\%), y en la proporción de pacientes menores de 15 años de edad (de 12,8\% a $8,7 \%$ ). En los pacientes multibacilares, los índices baciloscópicos promedio inicial y final fueron significativamente mayores en el período 2003-2007. En comparación con los casos del SINAN, en el ASA hubo más casos con discapacidad y en menores de 15 años de edad.

Conclusiones. Los pacientes con lepra de la zona metropolitana del Estado de Río de Janeiro pertenecen al estrato social más bajo y no se han beneficiado con el mejoramiento general de la situación socioeconómica en el Brasil. Brasil. 